\title{
ECOSYSTEM SERVICES OF RUSSIA
}

Introduction to TEEB Russia \& Extended Summary of TEEB Russia Volume 2

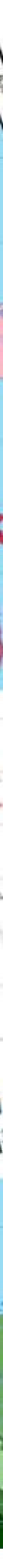

edited by

Elena Bukvareva and Karsten Grunewald 


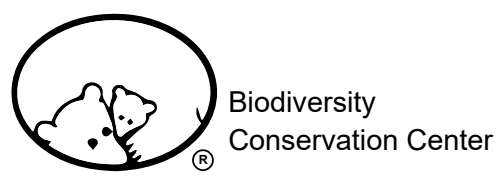

Leibniz Institute of

Ecological Urban and

Regional Development

Recommended citation:

Bukvareva, E. \& Grunewald, K. (2020) Introduction to TEEB Russia \& Extended Summary of TEEB Russia Volume 2. - DOI: https://doi.org/10.25366/2020.39

This extended summary introduces the TEEB Russia projects and sketches the main outlines of the comprehensive reports TEEB Russia Vols. 1 and 2. Commissioned by the German Federal Agency for Nature Conservation (BfN), the TEEB Russia projects were funded by the German Federal Ministry for the Environment, Nature Conservation and Nuclear Safety (BMU). They were supported by the Ministry of Natural Resources and Environment of the Russian Federation (MNR) with the active participation of experts from the Biodiversity Conservation Center (Moscow), Leibniz Institute of Ecological Urban and Regional Development (Dresden), Russian Academy of Sciences

(A. N. Severtsov Institute of Ecology and Evolution, the Institute of Geography, Center for Forest Ecology and Productivity, and the Institute for Systems Analysis), Lomonosov Moscow State University (the faculties of Biology, Geography, Economics and Zoological Museum), the Russian State Agrarian University - Moscow Timiryazev Agricultural Academy, and limited liability company «NextGIS».

Project coordinator: A.R. Grigoryan (BCC), K. Grunewald (IOER)

Project scientific leader: E.N. Bukvareva

Project website: http://teeb.biodiversity.ru/en/

(C) Biodiversity Conservation Center, Moscow, Russia

(C) Leibniz Institute of Ecological Urban and Regional Development, Dresden, Germany

Moscow/Dresden, July 2020 


\section{Content}

1

2

3

4
The story of TEEB Russia. 3

Ecosystem services of Russia: Why are they important? ........................................... 5

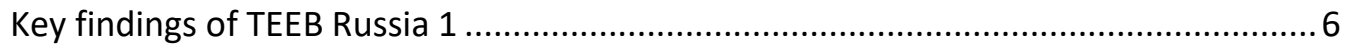

Objectives and key findings of TEEB Russia 2 ....................................................... 7

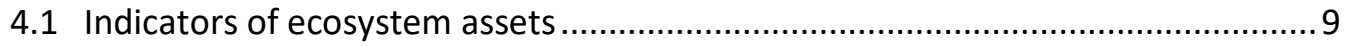

4.2 Refined estimate of ecosystem services for European Russia .............................11

Basic structure of ecosystem accounting in Russia .....................................................13

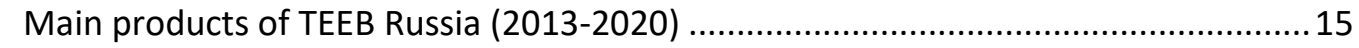

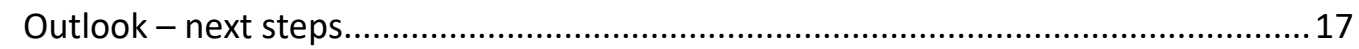

\section{List of figures}

Figure 1. The main blocks of the SEEA-EEA, reflected in the structure of the TEEB Russia 2 project.

Figure 2. Distribution of the analyzed $50 \times 50 \mathrm{~km}$ ecoregion cells in the European part of Russia.

Figure 3. Pollination index calculated for $50-\mathrm{km}$ squares and the subjects of RF within European Russia.

Figure 4. Relationships between provided ES of runoff volume by terrestrial ecosystems and the number of bird species.

\section{List of table}

Table 1. Indicators of the condition of ecosystem assets at national level and the main potential data sources for their assessment in Russia 


\section{The story of TEEB Russia}

\section{TEEB Russia: making Russia's ecosystems and biodiversity visible to the country and the world} The goal of TEEB (The Economics of Ecosystems and Biodiversity ${ }^{1}$ ) is to make nature's values visible. This is reflected in the TEEB Russia projects, which aimed to highlight the key importance of the country's ecosystems and biodiversity to its citizens, national and regional decision-makers, and the world community, as well as to stimulate the search for responsible ecosystem and biodiversity management approaches in Russia.

History

Since ancient times, Russians have understood the value of natural resources. Timber, furs and fish were previously vital pillars of the local economy, and in some cases also exported. The Russian and Soviet School of Forest Sciences has always emphasized the important woodland function of protecting soil and conserving water. The modern concept of ecosystem services (ES) has placed these issues in a new light $[6.1,6.2]$. In the early post-Soviet years, the first wave of Russian research on the economic valuation of $E S$ as well as biodiversity conservation strategy was fostered by the Global Environment Facility (GEF) project "Biodiversity Conservation of the Russian Federation". This work continued after the completion of the GEF project, involving dozens of organizations and Russia's regions. The end result was the country's first National Strategy for Biodiversity Conservation (2001) as well as a number of regional ES assessments (Kamchatka, Lower Volga, Moscow region, Tomsk and Yaroslavl Oblasts, etc.).

\section{The TEEB Russia project}

The motivating concept of TEEB is to integrate ecosystem services, namely the benefits that humans receive from the natural environment, with biodiversity, which is the structural basis of ES provisioning. In this way TEEB aims to raise the general awareness amongst decision-makers of the values of ES and biodiversity. From 2009, the Biodiversity Conservation Center (BCC, Moscow) worked to kickstart the TEEB process in Russia, in particular by organizing two conferences: "TEEB Project - Economics of Ecosystems and Biodiversity: Prospects for the Participation of Russia and other NIS Countries" (2010) ${ }^{2}$ and "Integration of Ecosystem Services in the Economy of the NIS Countries" (2011). ${ }^{3}$ Since 2013, the BCC has collaborated with the Leibniz Institute of Ecological Urban and Regional Development (Dresden) to implement the TEEB Russia project, which aims to develop ways of assessing Russia's ES and biodiversity. The TEEB Russia project is supported by the German Federal Agency for Nature Conservation (BfN) as well as the Ministry of Natural Resources and Environment of the Russian Federation (MNR). It receives funding from the German Federal Ministry of the Environment (BMU).

The initial project phase, TEEB Russia 1, which ran from 2013-2015, successfully realized the first national pilot assessment of ES in Russia. The second phase, TEEB Russia 2, which ran from 20182019, provided a preliminary set of national indicators for ES and ecosystem assets, including

\footnotetext{
${ }^{1}$ www.teebweb.org

${ }^{2}$ https://teeb.biodiversity.ru/en/conferences-in-russian/6-proekt-teeb-ekonomika-ekosistem-i-bioraznoobraziya-perspektivyuchastiya-rossii-i-drugikh-stran-nng.html (in Russian)

${ }^{3}$ https://teeb.biodiversity.ru/en/conferences-in-russian/5-integratsiya-ekosistemnykh-uslug-v-ekonomiku-stran-nng.html (in Russian)
} 
biodiversity, within the SEEA-EEA ${ }^{4}$ framework. The main results of TEEB Russia 1 and 2 are included in the Prototype National Reports on Ecosystem Services of Russia, Volumes 1 and 2 (see Sections 3 and 4).

\section{Awareness-raising}

The TEEB Russia project underlined for the general public the crucial impact of ES on the wellbeing of the population and the economic health of Russia's regions while also showing that ecosystems (ecosystem assets) must be considered key components of natural capital and national wealth. For people involved in solving environmental problems at different levels of authority and expertise, the project outlined general methodological ways to tackle ecosystem accounting in Russia.

Another concern of TEEB Russia was to clarify the role of biodiversity in the supply of ecosystem services. Despite the current scientific consensus on the key role of biodiversity in ecosystem functioning, there is no accepted, carefully defined approach to managerial decisions on biodiversity for vast territories such as Russia. The TEEB Russia projects made an important step forward by explaining to a Russian audience that natural ecosystems with typically low species diversity such as tundra or peat bogs are no less important for maintaining ES than high-diversity ecosystems. This principle of biodiversity and ES management is essential if we consider the extremely heterogeneous Russian territory, which encompasses ecosystems ranging from polar deserts to subtropical forests and semi-deserts, as well as in determining the country's central role in preserving biodiversity of Northern Eurasia. In the latter case, the implication is that boreal ecosystems are no less important for the conservation of the world's biodiversity and maintaining ES than tropical ones.

The results of TEEB Russia were published in Russian, German and English in a series of scientific papers (Chapter 6 ) and presented at important international conferences ${ }^{5}$ as well as regional scientific conferences within Russia. The final conference of TEEB Russia 2, held in Moscow in November 2019, was attended by around 70 representatives of scientific, environmental, international and public organizations from Russia, Belarus, Germany and other European countries. ${ }^{6}$ The TEEB Russia project significantly expanded the circle of scientists, students and management experts involved in the assessment of ES and biodiversity in Russia.

\section{The growing TEEB network}

The TEEB Russia project brought together a unique team of dozens of top Russian experts familiar with various aspects of the physical and economic assessment of ES and biodiversity as well as the Russian system of public statistics. Coordinated by the Biodiversity Conservation Center (BCC) in Moscow and the Leibniz Institute of Ecological Urban and Regional Development (IOER) in Dresden, leading researchers and contractors were recruited from the Russian Academy of

\footnotetext{
${ }^{4}$ United Nations. 2014. System of Environmental-Economic Accounting 2012: Experimental Ecosystem Accounting. New York: United Nations. (C) United Nations, European Union, Food and Agriculture Organization, Organization for Economic Co-operation and Development, World Bank Group. https://openknowledge.worldbank.org/handle/10986/23959 License: CC BY-NC-ND 3.0 IGO. (http://hdl.handle.net/10986/23959).

${ }^{5}$ ESP conferences 2014, 2016, 2019; IALE congress, 2015; ECOSERV conference, Poznan, Poland, 2018; Environmental Knowledge and Policy Innovation between East and West, Minsk, Belarus, 2019.

${ }^{6} \mathrm{https}: / /$ teeb.biodiversity.ru/en/conferences-in-russian/international-conference-november-2019.html
} 
Sciences and M.V. Lomonosov Moscow State University. In addition to these seasoned experts, students of Moscow State University participated in the assessment of various ES.

\section{Policy impact}

The TEEB Russia project has been implemented in close contact with the Ministry of Natural Resources and Environment of the Russian Federation (MNR). Project results have been repeatedly presented to staff of the MNR. In particular, the results were recognized and approved at the Russian-German Working Group meeting in 2019 as useful for the development of Russian environmental policy by representatives of the MNR and the German Federal Ministry for the Environment, Nature Conservation and Nuclear Safety (BMU). ${ }^{7}$ TEEB Russia's main suggestions for managing ES and biodiversity were set out in policy briefs addressed at decision-makers and government officials $[6.5,6.6]$.

Currently, the Federal State Statistics Service of the Russian Federation is beginning to implement the central framework of the System of Environmental-Economic Accounting (SEEA) as part of the System of National Accounts, including a discussion of ways to establish Experimental Ecosystem Accounts (EEA) in Russia. Thanks to the TEEB Russia project, core elements of the future national system of ecosystem accounting in Russia are ready for discussion by government officials and scientific experts.

One of the most important results of TEEB Russia is to keep Russia in line with global and international processes to create responsible policy regarding biodiversity and ES. The project has helped to strengthen the role of Russia in international nature conservation processes such as IPBES, CBD and TEEB as well as to incorporate the value of Russian ecosystems into international systems of environmental accounting (including the UNSD framework).

\section{Ecosystem services of Russia: Why are they important?}

The projects TEEB Russia 1 and 2 confirmed the crucial importance of ecosystem services for the well-being of the population and the sustainability of the economies of Russia's regions. Specifically, we can name the following factors:

- ES provide favourable environmental and living conditions (clean air/water) for the Russian population along with opportunities for fishing and hunting, picking mushrooms, berries and other "gifts of nature"; further, they determine the aesthetic and spiritual significance of nature.

- ES are important to maintain stable environmental conditions necessary for the smooth running of the Russian economy and for business (water/air purification, regulation of the water cycle, crop pollination, the prevention of soil erosion) as well as for the production of key biological resources such as timber, fish and game. The conservation of ecosystems and the maintenance of their sustainable functioning in Russia's regions will significantly reduce the damage to the economy and human health from negative environmental changes along with the cost of technological solutions necessary to deal with them.

\footnotetext{
${ }^{7}$ MNR RF press release of 2/7/2019; The Ministry of Environment of the RF is dealing with the issue of elaboration of an evaluation system for ecosystem services taking into account the conservation of biodiversity.

(http://www.mnr.gov.ru/press/news/v_minprirody_rossii_prorabatyvaetsya_vopros_sozdaniya_natsionalnoy_sistemy_otsenki_ekos istemnykh_usl/ (in Russian, accessed on 23/10/2019).
} 
- The absorption and storage of carbon by Russia's vast ecosystems are key ES with a global reach to help regulate the climate.

- Several of the most important regulating ES such as air/water purification and runoff regulation are already insufficient to deal with the task of maintaining an acceptable environmental quality in many regions of Russia.

Clearly, ecosystem services must be statistically evaluated and reflected in macroeconomic accounting. Those ecosystem assets should not only be regarded as important natural resources but also as factors contributing to the national wealth. Ecosystem assets should be appropriately quantified to allow inclusion in the balance of liabilities within the framework of the system of national accounts.

There is no doubt that effective nature management requires an adequate assessment, accounting and monitoring of ecosystems, biodiversity and ecosystem services. In this regard, the following aspects must be considered:

- Russia should be prepared to introduce ecosystem accounting in the framework of the system of environmental-economic accounting (SEEA-EEA) as the UN international standard, and be ready to begin implementing this system based on the local conditions of nature and the country's economic condition;

- The accounting of ecosystems, biodiversity and ecosystem services is necessary:

- for environmental impact assessment (EIA) and long-term spatial planning in Russia's regions;

- to attract foreign investments for major economic projects;

- to draw up an optimal policy for protected natural areas, both for the management of existing PAs (protected areas) and for the development of a network of PAs;

- A form of ecosystem accounting that obeys UN standards is needed to meet the UN's sustainable development goals (SDGs) 15 and 17.

\section{Key findings of TEEB Russia 1}

\section{Abstract of Volume 1 of the Prototype National Report on Ecosystem Services of Russia [6.3]}

The report is the first national assessment of Russia's ecosystem services that considers terrestrial natural ecosystems. A methodology for ES assessment was developed to make use of current national statistics. The units of ES assessment are the federal subjects (or constituent entities) of the Russian Federation. ${ }^{8}$ An assessment was made of ES volumes supplied by ecosystems and consumed by humans. A number of provisioning and regulating ES were evaluated by means of physical indicators; others were scored in terms of natural and socioeconomic factors that determine the supply and use of ES. The degree to which ES are consumed by humans was assessed by the ratio of supplied to consumed ES volumes. The federal subjects of the Russian Federation were compared with respect to supplied and consumed ES volumes. This enabled the identification of regions that are ES donors and those which are ES recipients.

\footnotetext{
${ }^{8}$ The federal subjects of Russia are the country's constituent entities, namely the top-level political divisions of the Russian Federation.
} 


\section{Key findings}

- In view of the extreme diversity of natural and socioeconomic conditions in Russia, it is necessary to conduct separate assessments of supplied (potential) ES (i.e. ES produced by ecosystems regardless of the presence or absence of ES consumers), demanded ES (i.e. the ES amount necessary to meet the needs of the population and the regional economy) and consumed ES (i.e. the ES yield which is materially or immaterially used by the population, or from which people derive current benefits). The ratios of and disparities between supplied, demanded and consumed ES indicate the level of use of ES in the regions as well as the extent to which needs are being satisfied.

- Terrestrial ES are critical for the well-being of local people and a healthy Russian economy. The volume of the most important ecosystem services has been analysed and compared to the basic needs of the population and economy of the Russian regions for regulating the environment, for natural bio-production and recreational services.

- The services of Russian ecosystems to absorb and store carbon are key global factors for climate regulation.

- A number of the most important regulating ES are either fully consumed or already insufficient to meet the needs of the people and the economy. This is true of runoff regulation, water purification by terrestrial and aquatic ecosystems as well as the absorption of air pollutants by suburban forests.

- The uneven distribution of supplied, demanded and consumed ES means that some regions are ES donors and others recipients. These disparities must be considered in national and multiregional planning and when developing ES markets. One approach to comparing regions was demonstrated in the project.

- Currently, ES are not regulated by the state and are not subject to special monitoring. ES are not adequately assessed or taken into account in decision-making, except in the case of some commercially important provisioning ES (i.e. timber, fish, game) and forest-related regulating ES. There is incomplete monitoring of natural ecosystems (except for forests); furthermore, the identified components of biodiversity are incomplete and do not reflect modern technical standards.

- It is vital to begin establishing a national system of ES monitoring and assessment as well as mechanisms to integrate ES values in decision-making. Otherwise the environmental safety and sustainable development of Russia will be threatened, and the global benefits of this ES donor country will be lost.

The results of the TEEB Russia 1 project were further revised and published in high-ranking international journals [6.7-6.12].

\section{Objectives and key findings of TEEB Russia 2}

\section{Abstract of Volume 2 of the Prototype National Report on Ecosystem Services of Russia [6.4]}

The report presents the results of the second phase of the TEEB Russia project. Specifically, it discusses ways of developing Experimental Ecosystem Accounting within the framework of the System of Environmental-Economic Accounting of natural-economic accounting (SEEA-EEA) in Russia. Further, a preliminary set of physical indicators for ecosystem services and ecosystem assets is proposed. Indicators of ecosystem services include the provided (potential), consumed 
and, in some cases, the required volumes. Indicators of ecosystem assets include measures of their extent (ecosystem area) and condition (i.e. biodiversity and ecosystem productivity as measured by the richness of bird- and higher plant species as indicators and ecosystem functioning as measured by phytomass). The report confirms the need for a regionally differentiated approach to SEEA-EEA in Russia. Correlations between climatic parameters, indicators of ecosystem services and ecosystem assets are analyzed. It is shown that while the identified correlations cannot serve as a direct basis for decision-making at the national and subnational scales, they are vital to help form regionally differentiated management approaches. A pilot economic assessment of ecosystem services and ecosystem assets has shown that these components of natural capital are key to the well-being of the local people in Russia's regions.

\section{Objective}

The aim of TEEB Russia 2 was to further develop the methodology of ecosystem accounting in the SEEA-EEA framework by integrating ES indicators proposed by TEEB Russia 1, supplemented by indicators of ecosystem assets.

In addition to the physical extent of ecosystems, abiotic and biotic indicators (including biodiversity) of the condition of ecosystems tell us about the capacity to provide ES. Therefore, the main tasks of the TEEB Russia 2 project were to analyze ways of integrating such indicators of $E S$, the physical extent of ecosystems, phytomass, productivity and biodiversity in the framework of ecosystem accounting as well as to identify relationships between these indicators

Figure 1 offers a schematic overview of the key areas investigated by TEEB Russia 2.

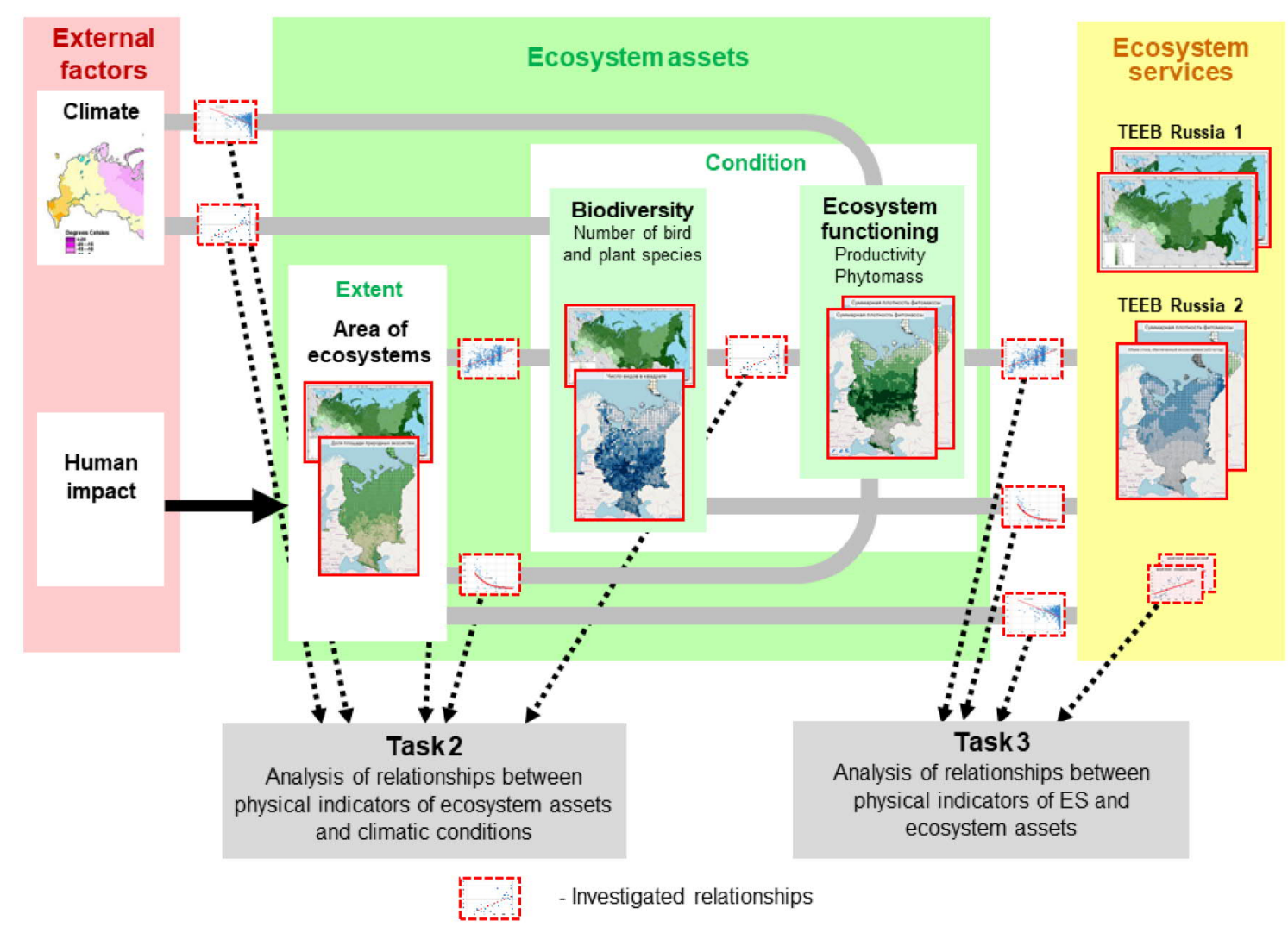

Figure 1. The main blocks of the SEEA-EEA, reflected in the structure of the TEEB Russia 2 project. 
Data on the condition of ecosystems, including biodiversity indicators and physical estimates of $\mathrm{ES}$, was analyzed at the national and subnational scales for the following territorial units:

- The federal subjects of the Russian Federation (hereinafter RF) throughout the country or within European Russia;

- ecoregions based on the map provided by the World Wildlife Fund ${ }^{9}$ within European Russia (see Fig. 2);

- $50 \times 50 \mathrm{~km}$ cells within European Russia (Fig. 2) as used by the Atlas of Breeding Birds of European part of Russia ${ }^{10}$ and reflecting the framework of European Breeding Bird Atlas. ${ }^{11}$
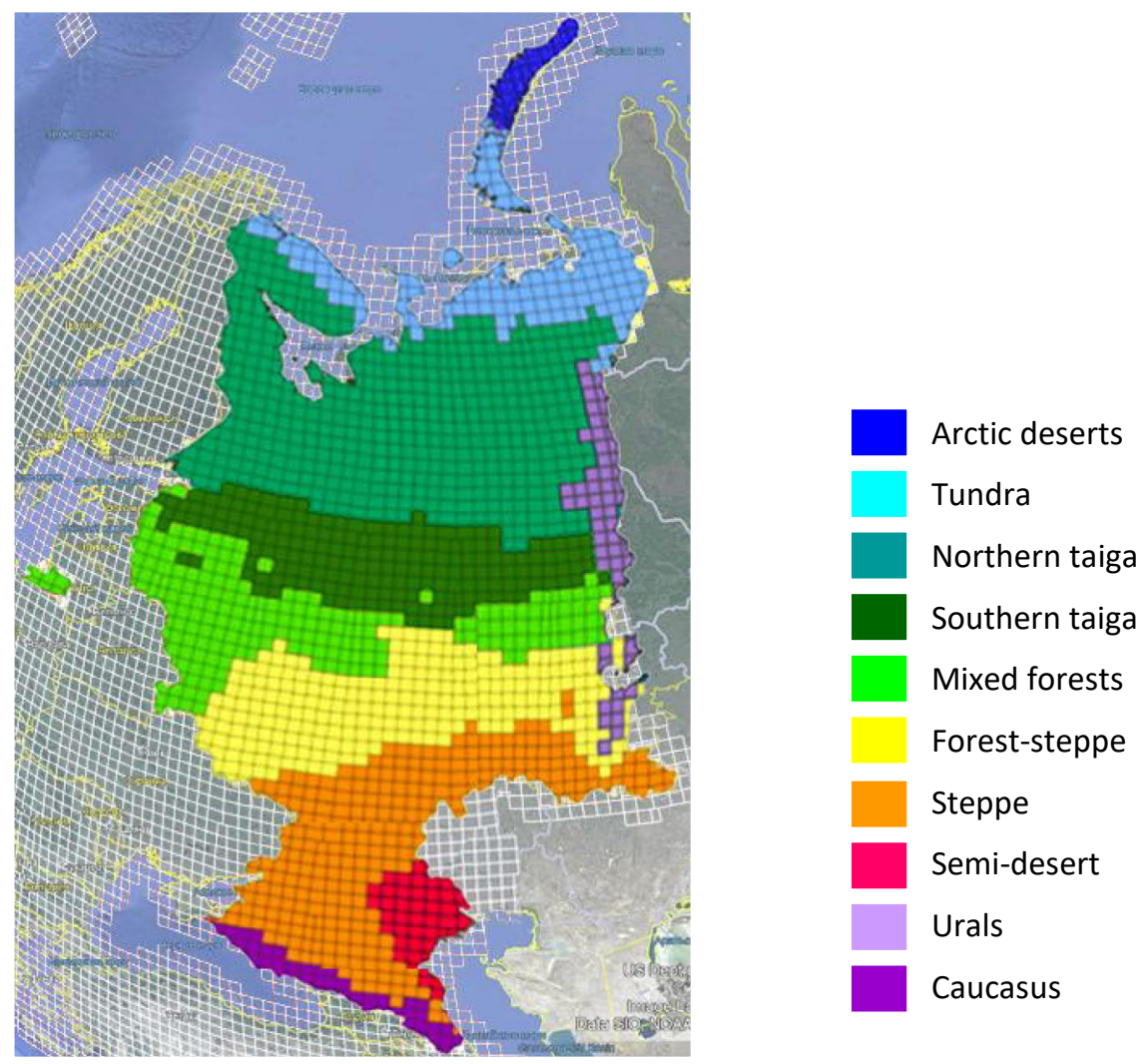

Figure 2. Distribution of the analyzed $50 \times 50 \mathrm{~km}$ ecoregion cells in the European part of Russia.

\subsection{Indicators of ecosystem assets}

Ecosystem assets are defined as "contiguous areas covered by a specific ecosystem". A basic principle associated with the delineation of ecosystem assets is that their extent provides a complete and non-duplicative set of assets that make up the ecosystem accounting area.

\footnotetext{
${ }^{9}$ Olson, D.M., Dinerstein, E., Wikramanayake, E.D., Burgess, N.D., Powell, G.V.N., Underwood, E.C., D'Amico, J.A., Itoua, I., Strand, H.E., Morrison, J.C., Loucks, C.J., Allnutt, T.F., Ricketts, T.H., Kura, Y., Lamoreux, J.F., Wettengel, W.W., Hedao, P., Kassem, K.R. (2001). Terrestrial ecoregions of the world: a new map of life on Earth. Bioscience, 51(11), 933-938.

10 http://zmmu.msu.ru/musei/struktura_muzeya/sektor-nauchno-obshhestvennykh-proektov/atlasgnezdyashhikhsya-ptic-evropejskoj-rossii

${ }^{11}$ https://www.ebba2.info/
} 
Ecosystem types, meanwhile, are defined as "aggregations of individual ecosystem assets of a specific type of ecosystem". ${ }^{12}$

In order to realize an exhaustive accounting of ecosystem conditions and services, we need a shared informational basis of changes in the spatial extent of diverse ecosystems, i.e. an ecosystem extent account. The ecosystems must be classified in accordance with the subsequent accounting of their condition and services, which can vary greatly depending on regional and local ecological, economic and social conditions. ${ }^{13}$

In Russia, an ecosystem monitoring system in the prescribed form has not yet been established. However, nationwide maps of vegetation or ecoregions can be initially employed as data sources. While changes in the proportion of land cover could be monitored by remote-sensing data, it would be difficult to ensure a standard form and sufficient resolution over such a vast country.

In TEEB Russia 2, the following indicators of the condition of ecosystems were processed and mapped for the European part of Russia:

- The degree of territory transformation, calculated as the proportionate area of fully transformed ecosystems (arable lands and urbanized zones) according to the vegetation map of Russia.

- The total phytomass density and net primary production of natural ecosystems, calculated using data from Land Resources of Russia ${ }^{14}$.

- Biodiversity indicators - the richness of bird and vascular plant species based on data from the Atlas of Breeding Birds of the European part of Russia as well as data from the relevant literature.

The above indicators are discussed in detail (data, maps, analyses) in Vol. 2 of the TEEB Russia report (see [6.4]). Their relationships with each other and with ES indicators as well as opportunities to utilize indicators in SEEA-EEA are discussed in each case (see Section 5 for preliminary key findings on ecosystem accounting in Russia).

In Table 1 we list the indicators currently available in Russia that could be used to capture the extent and condition of ecosystem assets.

\footnotetext{
12 United Nations (UN), 2017, Technical Recommendations in support of the System of Environmental-Economic Accounting 2012 Experimental Ecosystem Accounting, White cover publication.

${ }^{13}$ Grunewald K, Schweppe-Kraft B, Syrbe R-U, Meier S, Krüger T, Schorcht M, Walz U (2020)

Hierarchical classification system of Germany's ecosystems as basis for an ecosystem accounting - methods and first results. One Ecosystem 5: e50648. https://doi.org/10.3897/oneeco.5.e50648

14 https://webarchive.iiasa.ac.at/Research/FOR/russia_cd/veg_maps.htm\#npp
} 
Table 1. Indicators of the condition of ecosystem assets at national level and the main potential data sources for their assessment in Russia (marine ecosystems not considered).

\begin{tabular}{|c|c|}
\hline Indicator & Data source \\
\hline \multicolumn{2}{|c|}{ Area and the degree of ecosystem disturbance } \\
\hline Area of ecosystems & \multirow{2}{*}{$\begin{array}{l}\text { - Vegetation map (regular updates required) } \\
\text { - Remote-sensing data }\end{array}$} \\
\hline Fragmentation of natural ecosystems & \\
\hline \multicolumn{2}{|l|}{ Biomass and productivity } \\
\hline Phytomass of ecosystems & Remote-sensing data \\
\hline Wood stocks & Federal Forestry Agency of RF \\
\hline Ecosystem productivity & Remote-sensing data \\
\hline \multicolumn{2}{|l|}{ Biodiversity } \\
\hline Diversity of ecosystems & $\begin{array}{l}\text { - Vegetation map (regular updates required) } \\
\text { - Remote-sensing data }\end{array}$ \\
\hline Diversity of bird species & $\begin{array}{l}\text { - Atlas of breeding birds of European Russia } \\
\text { - Regional and local surveys for the Asian part of } \\
\text { Russia }\end{array}$ \\
\hline Diversity of vascular plant species & $\begin{array}{l}\text { - For Central Federal District: projects "Flora of the } \\
\text { Oka Basin" and "Flora of the Central Black Earth } \\
\text { Region" } \\
\text { - For the rest of country: local surveys }\end{array}$ \\
\hline Species diversity in protected areas & Ministry of Natural Resources and Ecology of RF \\
\hline The number of Red List species & Ministry of Natural Resources and Ecology of RF \\
\hline $\begin{array}{l}\text { Abundance and diversity of game } \\
\text { animals }\end{array}$ & Ministry of Natural Resources and Ecology of RF \\
\hline $\begin{array}{l}\text { Abundance and diversity of } \\
\text { freshwater commercial fish }\end{array}$ & Federal Agency for Fisheries of RF \\
\hline \multicolumn{2}{|l|}{ Abiotic indicators } \\
\hline Runoff volume & \multirow{2}{*}{$\begin{array}{l}\text { Federal Service for Hydrometeorology and } \\
\text { Environmental Monitoring }\end{array}$} \\
\hline Runoff variability & \\
\hline \multicolumn{2}{|l|}{ Pollution } \\
\hline Air pollution & \multirow{3}{*}{$\begin{array}{l}\text { - Federal State Statistics Service } \\
\text { - Federal Service for Hydrometeorology and } \\
\text { Environmental Monitoring }\end{array}$} \\
\hline Water pollution & \\
\hline Soil pollution & \\
\hline
\end{tabular}

\subsection{Refined estimate of ecosystem services for European Russia}

While the assessment of ES in TEEB Russia 1 was highly aggregated for the federal subjects of Russia, TEEB Russia 2 provided a more detailed analysis of selected ES for ecoregions; in particular, a grid of $50 \mathrm{~km} \times 50 \mathrm{~km}$ cells was mapped for European Russia. Furthermore, some additional ES were processed. In detail, the following ES were mapped and assessed within TEEB Russia 2:

- Timber production

- Carbon storage

- Air purification by suburban forests

- Regulation of runoff volume by terrestrial ecosystems

- Prevention of soil erosion by running water

- Pollination

- Creation of natural conditions for weekend recreation 
- Aesthetic values of ecosystems and landscapes

- Ecosystem services of Russia's largest cities (urban ES are to be discussed in a separate report, currently in preparation).

As an example, we briefly discuss the results for pollination (see Fig. 3). This ecosystem service was assessed on the basis of three generalized indexes: pollination provided by natural ecosystems (for 50-km squares and federal subjects of the European part of the RF); pollination needed for agriculture; and the degree to which the demand for pollination is satisfied (for federal subjects of the European part of the RF). Pollination potential is significant in the forest steppe and steppe ecoregions and highest in the steppe regions of Volgograd and Rostov oblasts.
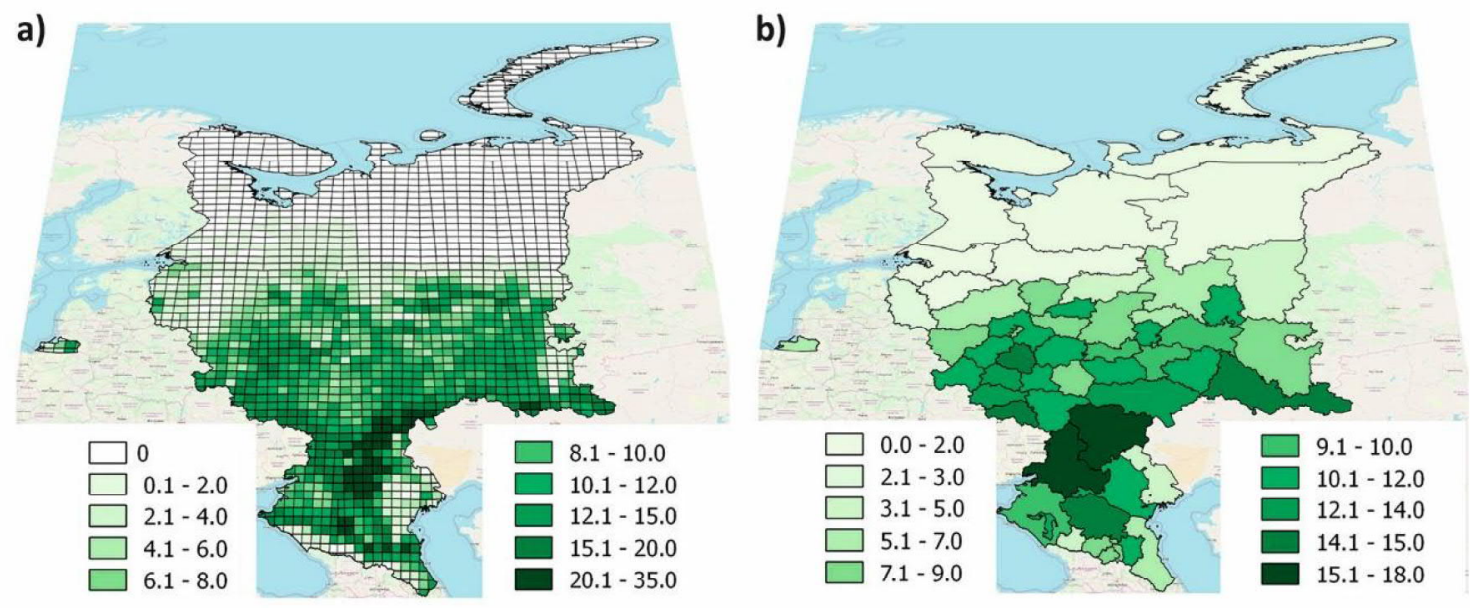

Figure 3. Pollination index calculated for 50-km squares and the subjects of RF within European Russia.

\subsection{Ecosystem services for Russia's indigenous peoples}

One section of the TEEB Russia 2 report investigated the importance of ecosystem services for preserving the culture and traditional way of life of the indigenous peoples of Russia.

At present, the country has 47 so-called "indigenous small-numbered peoples" (ISPN) with a total population of $316,000.40$ of these peoples ${ }^{15}$ are named in the Inventory of Indigenous Smallnumbered Peoples of the North, Siberia and Far East of the Russian Federation.

ES are crucial to the survival of the ISPN and the preservation of their cultural identity. These are primarily provisioning services, namely:

- fodder from natural pastures;

- marine ecosystem products (largely marine mammals and fish);

- freshwater ecosystem products (largely fish);

- wild game hunting in terrestrial ecosystems.

The report discusses a number of key problems (and approaches to solving them) that must be considered to ensure the survival of the ISPN and their traditional use of northern ecosystems. The authors of Volume 2 conclude that the ISPN's special knowledge and ways of life in regard to migratory routes, opportunities for maneuver in emergency situations, sacred and forbidden places to visit, and related natural objects, together constitute an important information

15 The Aleuts, Aleutors, Veps, Dolgans, Itelmens, Kamchadals, Kereks, Kets, Koryaks, Kumandins, Mansis, Nanais, Nganasans, Negidalts, Nenets, Nivkhs, Oroks (Ulta), Orochs, Samis, Tazes, Telengits, Teleuts, Tofalars, Tubulars, Tozhu Tuvins, Udegeis, Ulchs, Khantis, Chelkans, Chukchis, Chulyms, Shors, Evenks, Evens, Ents, Eskimos and Yukaghirs. 
ecosystem service that must be preserved for the sustainable development of nature management by these natives.

\section{Basic structure of ecosystem accounting in Russia}

Relationships between indicators of ecosystem assets, ecosystem services, and climatic conditions were analyzed in TEEB Russia 2. In view of the identified disparities in the average values of indicators and the correlations between them in different ecoregions, the following preliminary conclusions on establishing an ecosystem accounting in Russia could be drawn [6.4]:

\section{(1) The Russian national system of ecosystem accounting must be regionally differentiated}

The sets of indicators of ES and ecosystem assets as well as their interpretation for decisionmaking should reflect disparities in the structure and functioning of ecosystems in regions with different environmental conditions and which show varying degrees of anthropogenic transformation.

The values of indicators and the dependencies between these differ most in the group of northern, forest and mountain ecoregions (Arctic deserts, tundra, northern taiga, southern taiga, mixed forests, Urals, Caucasus) and the group of southern ecoregions (forest-steppe, steppe, semidesert). One example is shown in Fig. 4. In some cases, specific relationships were identified between indicators for mountain ecoregions and for forest-steppe. In addition, significant differences were revealed between a group of relatively weakly transformed ecoregions (northern, forest, mountain ecoregions and semi-desert) and strongly transformed agricultural regions (forest-steppe, steppe).

In general, regions with more severe conditions (northern and arid) are characterized by lower levels of species diversity, phytomass and ecosystem productivity. Yet this does not mean that the ecosystem assets of these regions are less valuable for preserving biodiversity and providing ES. Rather, the relatively low levels of biodiversity and phytomass in undisturbed ecosystems in these regions can be explained by their adaptation to physical-topographic conditions; in this way, they provide the most effective and stable ecosystem functioning and regulating ES.

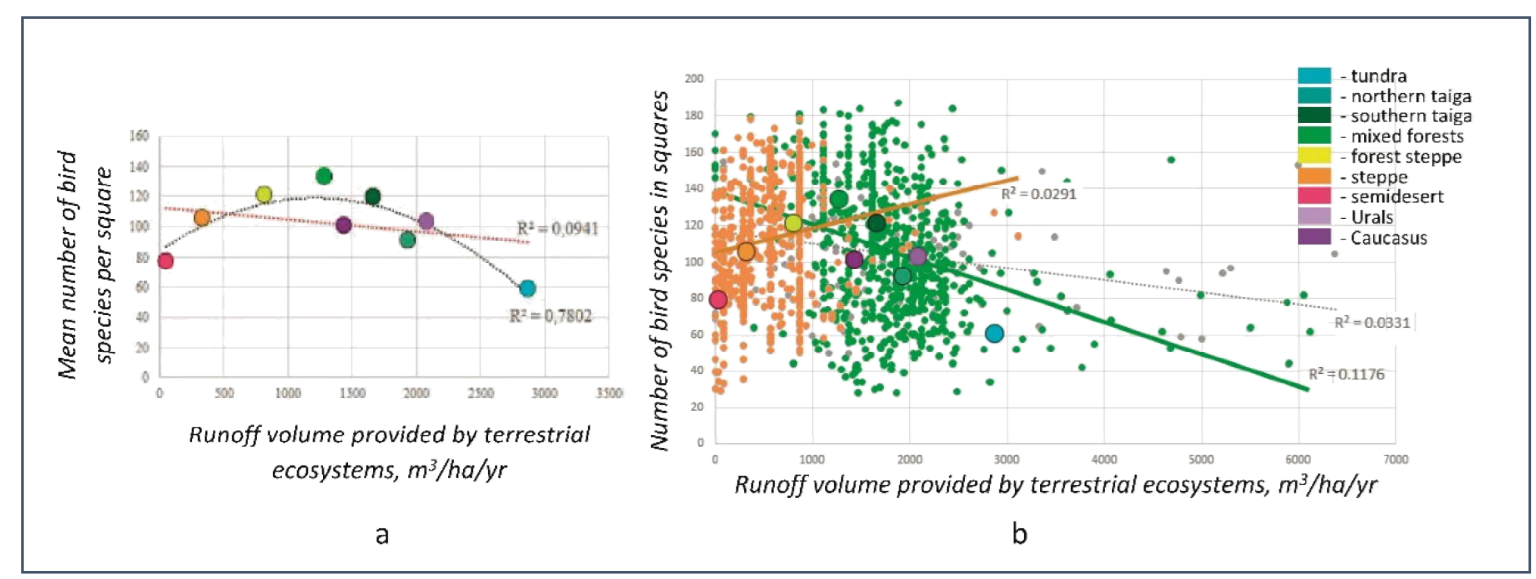

Figure 4. Relationships between provided ES of runoff volume by terrestrial ecosystems and the number of bird species: a) mean values for the ecoregions; b) 50-km cells within European Russia in the group of northern, forest and mountain ecoregions (marked in green) and in the group of southern ecoregions (marked in orange); the dependencies for the whole of European Russia is given by the dashed line. The coloured circles are the average values of indicators for individual ecoregions (in accordance with the colour-coding of Fig. 2). This analysis excludes the arctic desert ecoregion. 
Approaches to the economic valuation of ES and ecosystem assets as well as the interpretation for decision-making should also be regionally differentiated to reflect the extremely uneven distribution of ES values and ecosystem assets across Russia's regions. In economically developed regions with a high population density, ecosystem assets are largely degraded due to human activities; while their value is low compared to the value of economic assets, demand for ES is nonetheless high. In regions with low population density and weakly modified ecosystems, in contrast, the value of ecosystem assets may exceed that of economic assets, but the demand for ES is relatively low. Obviously, the methods and interpretation of the economic valuation of ES and ecosystem assets should be different in these cases.

(2) The interpretation of indicator values of ES and ecosystem assets (when addressed to government officials and policymakers) should take into account the nature of the revealed correlations: namely, whether these correlations reflect causal relationships between indicators or can be attributed to the simultaneous reaction of indicators to changes in other factors.

Correlations between indicators of ES and ecosystem assets revealed in the TEEB Russia 2 project at the national and subnational (for the European territory of Russia) scales do not generally reflect causal relationships but can rather be attributed to the simultaneous reaction of indicators to changes in climatic conditions as well as to the degree of anthropogenic transformation of the territory (which in turn depends on climatic conditions). While these correlations cannot serve as a direct basis for decision-making, they can help accomplish some tasks in the formation of SEEAEEA, namely: a) to identify the similarities and differences between Russia's regions when developing a regionally differentiated approach to ecosystem accounting; $b$ ) to pinpoint groups of indicators that change in a similar way in response to certain factors; $c$ ) to uncover trade-offs or synergies between ES as well as ES bundles, i.e. groups of mutually reinforcing or supporting ES.

(3) Biodiversity, phytomass, and ecosystem productivity are important indicators of the condition of ecosystem assets and their potential for delivering ES.

Biodiversity is considered by the scientific community as crucial to ecosystem functioning and the delivery of ecosystem services. ${ }^{16} \mathrm{~A}$ decrease in the values of biodiversity indicators in any locality or on average in a region indicates the degradation of ecosystem assets, which can in turn undermine provisioning ES.

The biodiversity indicators analyzed in the TEEB Russia 2 project, i.e. diversity of bird species (indices of species richness, conservation status and synanthropization) and richness of higher plant species, were shown to be suitable for assessing the condition of ecosystem assets. Today, the best data coverage on bird species is found in the European part of Russia. In contrast, data collection on bird diversity must be intensified in the Asian part of Russia and expanded to include other groups of organisms (plants, insects and other animals) in the monitoring programmes. Yet given the limited possibilities for the detailed monitoring of biodiversity throughout the country in the near future, extrapolation methods must be developed to assess biodiversity in those cases where primary data is insufficient. By employing such methods, biodiversity assessments can make use of currently available data on flora and fauna, cartographic and remote-sensing data, as well as expert estimates. Focused studies at the regional and local levels are required to clarify the set of biodiversity indicators and approaches to their interpretation.

\footnotetext{
16 IPBES (2018). The IPBES regional assessment report on biodiversity and ecosystem services for Europe and Central Asia / Rounsevell, M., Fischer, M., Torre-Marin Rando, A. and Mader, A. (eds.). Germany, Bonn: Secretariat of the Intergovernmental Science-Policy Platform on Biodiversity and Ecosystem Services (see Section 3.2) https://ipbes.net/assessment-reports/eca.
} 
(4) The structure of SEEA-EEA indicators and their interpretation should consider the probability of a significant change in relationship between indicators at different scales and levels of management.

Correlations between indicators of ES and ecosystem assets can vary greatly at different scales, even changing sign, i.e. when moving from the scale of the whole country or large regions (European territory of Russia) to the scale of a group of ecoregions or individual ecoregions, positive correlations can change to negative, and vice versa (an example is shown in Fig. 4 b). Therefore, the absence of correlation on one scale does not imply a similar lack of correlation between parameters on another scale. Despite the fact that, at the national and subnational scales, correlations between indicators of ES and ecosystem assets cannot directly form the basis for decision-making (see above), one should expect manifestations of causal relationships at the local level, reflecting the impact of biodiversity on ecosystem functioning and ES. In this way, estimates and conclusions made for one scale cannot be directly transferred to other scales.

\section{Main products of TEEB Russia (2013-2020)}

\section{Basic brochures}

[6.1] Grunewald, K., Bastian, O., Drozdov, A. (Eds.) (2014) TEEB-Prozesse und ÖkosystemAssessment in Deutschland, Russland und weiteren Staaten des nördlichen Eurasiens (TEEB процессы и экосистемные оценки в Германии, России и в некоторых других странах Северной Евразии). BfN-Skripten 372, Bonn, 372 S. https://www.bfn.de/fileadmin/BfN/service/Dokumente/skripten/Skript_372.pdf

[6.2] Grunewald, K., Bastian, O., Drozdov, A., Grabowsky, V. (Eds.) (2014) Erfassung und Bewertung von Ökosystemdienstleistungen (ÖSD) - Erfahrungen, insbesondere aus Deutschland und Russland (Учет и оценка экосистемных услуг (ЭУ) - Опыт, особенно Германии и России). BfN-Skripten 373, Bonn, 371 S.

https://www.bfn.de/fileadmin/BfN/service/Dokumente/skripten/Skript_373.pdf

Main scientific project reports

[6.3] Bukvareva, E.N., Zamolodchikov, D.G. (Eds.) (2018) Ecosystem services of Russia: Prototype National Report. Vol. 1. Terrestrial ecosystems services. Adapted English version of the report, originally published in Russian in 2016. Moscow: BCC Press. http://www.biodiversity.ru/programs/ecoservices/first-steps/Ecosystem-Services-Russia_V1_eng_web.pdf; Russian version: https://teeb.biodiversity.ru/publications/Ecosystem-Services-Russia_V1_web.pdf

[6.4] Bukvareva, E.N., Sviridova, T. V. (Eds.) (2020) Ecosystem services of Russia: Prototype National Report. Vol. 2. Biodiversity and Ecosystem Services: Accounting Principles in Russia. English version of the report published originally in Russian in 2020.

Moscow: BCC Press. http://teeb.biodiversity.ru/publications/Ecosystem-Services-Russia_V2_eng_web.pdf Russian version: http://teeb.biodiversity.ru/publications/Ecosystem-Services-Russia_V2_web.pdf 
Policy papers / Summaries for decision-makers

[6.5] TEEB Russia 1: Policy Brief (2016): https://teeb.biodiversity.ru/publications/Prototype_for_decisionmakers_rus.pdf (in Russian); https://teeb.biodiversity.ru/publications/Prototype_for_decision-makers.pdf (in English);

[6.6] TEEB Russia 2: Policy Brief (2020): https://teeb.biodiversity.ru/publications/Prototype_for_decisionmakers_V2_rus.pdf (in Russian); http://teeb.biodiversity.ru/publications/Prototype_for_decision-makers_V2_eng.pdf (in English)

Scientific papers

[6.7] Grunewald, K., Bastian, O., Schmauder, H. (2014) Initialisierung eines deutsch-russischen TEEB-Prozesses. Natur und Landschaft, 89. Jg. Heft 2, S. 88-89

[6.8] Bastian, O., Grunewald, K., Khoroshev, A.V. (2015) The significance of geosystem and landscape concepts for the assessment of ecosystem services - exemplified in a case study in Russia. Landscape Ecology. Volume 30, Issue 7: 1145-1164, DOI: 10.1007/s10980-0150200-x.

[6.9] Bukvareva, E.N., Grunewald, K., Bobylev, S.N., Zamolodchikov, D.G., Zimenko, A.V., Bastian, O. (2015) The current state of knowledge of ecosystems and ecosystem services in Russia. A status report. AMBIO 44(6): 491-507. DOI 10.1007/s13280-015-0674-4

[6.10] Grunewald, K., Bastian, O., Bukvareva, E.N., Zimenko, A.V., Grabovsky, V.I., Schmauder, H. (2016) Erfassung und Bewertung der Ökosystemleistungen Russlands: ein Status-quo Bericht. Natur und Landschaft 91(4): 170-178

[6.11] Bukvareva, E., Zamolodchikov, D., Kraev, G., Grunewald, K., Narykov, A. (2017) Supplied, demanded and consumed ecosystem services: Prospects for national assessment in Russia. Ecological Indicators 78: 351-360

(http://dx.doi.org/10.1016/j.ecolind.2017.03.034)

[6.12] Bukvareva, E.N.; Zamolodchikov, D.G.; Grunewald, K. (2019) National assessment of ecosystem services in Russia: Methodology and main problems. Science of the Total Environment 655, S. 1181-1196 (https://doi.org/10.1016/j.scitotenv.2018.11.286)

Project web site: http://teeb.biodiversity.ru/en/ 


\section{Outlook - next steps}

Based on the findings of TEEB Russia 1 and 2, the following steps have been identified as facilitating the assessment and accounting of ecosystems and their services as well as the implementation of results in policy, decision-making, planning and management:

- Preparation and dissemination of the results/documents of the TEEB Russia projects $1 \& 2$ to a wide professional audience.

- Processing and inclusion of results in IPBES reports, TEEB international activities, SEEA approaches (UN/OECD) and CBD activities.

- Informing citizens and decision-makers on "the importance of urban nature for the health and quality of life of the Russian population" (comprehensive report on the values of urban nature using the example of Moscow and other cities of the Russian Federation).

- Preparation and coordination of essential contents of a potential next project phase (TEEB Russia 3) to further develop approaches and methods for ecosystem accounting as well as to draw up recommendations for a pilot regional implementation based on existing results of ecosystem/biodiversity assessments from the TEEB 1 and 2 studies. 


\section{The editors of the report}

Dr. Elena N. Bukvareva

Biologist, expert in biodiversity and ecosystem services

Scientific leader of projects dealing with ecosystem services

Biodiversity Conservation Center, Moscow, Russia

Email: bukvareva @gmail.com

Dr. Karsten Grunewald

Landscape ecologist, expert in ecosystem services assessment and accounting

Senior researcher and project leader

Leibniz Institute of Ecological Urban and Regional Development, Dresden, Germany

Email: k.grunewald@ioer.de

\section{Authors involved in TEEB Russia Vol. 1}

S.N. Bobylev, E.N. Bukvareva, A.A. Danilkin, Y.Y. Dgebuadze, A.V. Drozdov, O.F. Filenko, V.I. Grabovsky, A.V. Khoroshev, G.N. Kraev, R.A. Perelet, I.E. Smelyansky, B.R. Striganova, A.A. Tishkov, D.G. Zamolodchikov; Maps prepared by A.N. Narykov

\section{Authors involved in TEEB Russia Vol. 2}

K.A. Aleksandriiskaia, S.N. Bobylev, E.N. Bukvareva, A.A. Danilkin, A.V. Drozdov, M.Yu. Dubinin, A.D. Dumnov, V.I. Grabovsky, O.A. Illarionova, M.V. Kalyakin,

A.V. Khoroshev, O.A. Klimanova, E.Yu. Kolbovskii, S.N. Lysenkov, O.A. Murashko,

S.A. Ostroumov, R.A. Perelet, G.I. Ruban, A.S. Semenova, A.V. Shcherbakov,

S.V. Solovyeva, T.V. Sviridova, O.V. Voltzit, E.S. Yesipova

International experts involved in TEEB Russia Vol. 2

K. Grunewald (IOER Dresden), L. Kümper-Schlake, K. Wenzel (BfN Bonn)

The original TEEB Russia 2 study was prepared in Russian. The translation of the Russian text into English was done by KERN AG, Sprachendienste in Frankfurt am Main.

We would like to thank Mr. Derek Henderson for the final language review of this summary report. 
